\title{
Cost of care of patients with cystic fibrosis in The Netherlands in 1990-1
}

\author{
Mark F Wildhagen, Joke B G M Verheij, Henk B M Hilderink, Loes Kooij, \\ Tjeerd Tijmstra, Leo P ten Kate, Jorrit Gerritsen, Wim Bakker, \\ J Dik F Habbema
}

Department of Public Health,

Erasmus University

Rotterdam

PO Box 1738

3000 DR Rotterdam,

The Netherlands

M F Wildhagen

H B M Hilderink

J D F Habbema

Department of

Medical Genetics,

University of

Groningen

J B G M Verheij

Department of Health

Sciences/Northern

Centre for Health

Care Research,

University of

Groningen

L Kooij

T Tijmstra

Department of Human

Genetics, Free

University Amsterdam

L P ten Kate

Beatrix Children's

Clinic, University

Hospital Groningen

J Gerritsen

Leyenburg Hospital,

Department of

Pulmonology,

Adult Cystic Fibrosis

Centre, The Hague

W Bakker

Correspondence to:

Dr M F Wildhagen.

Received 20 July 1995

Returned to authors

11 September 1995

Revised version received

25 September 1995

Accepted for publication

3 October 1995

\begin{abstract}
Background - Research on the cost of care of patients with cystic fibrosis is scarce. The aim of this study was to estimate the costs using age-specific medical consumption from real patient data.

Methods - The age-specific medical consumption of patients with cystic fibrosis in The Netherlands in 1991 was estimated from a survey of medical records and a patient questionnaire. A distinction was made between costs of hospital care, hospital and non-hospital medication, and home care. Costs per year were obtained by multiplying the yearly amount of care and the costs per unit.
\end{abstract}

Results - On average the annual cost of a patient with cystic fibrosis in 1991 was £10908 (hospital care 42\%, medication $37 \%$, home care $20 \%$ ). The cost of care of cystic fibrosis in The Netherlands, with approximately 1000 patients, is estimated at $£ 10.9$ million per year, which is $0.07 \%$ of the total health care budget. The cost of care of a patient up to the age of 35 is estimated at $£ 614587$. When year-to-year survival is taken into account and future costs are discounted to the year of birth with a yearly discount rate of $5 \%$, the cost of care of a patient with cystic fibrosis is estimated at $£ 164365$ for 1991 . This estimate will be used in a prospective evaluation of screening for cystic fibrosis carriers.

Conclusions - The cost of care of patients with cystic fibrosis estimated by age-specific medical consumption of real patients is higher than that estimated by non-agespecific medical consumption and/or expert opinions.

(Thorax 1996;51:298-301)

Keywords: cystic fibrosis, cost of care, The Netherlands.

Cystic fibrosis is the most common serious autosomal recessive disease in many white populations. Despite the progress made in clinical management during the last three decades it remains, in most patients, a disease with a limited life expectancy. In The Netherlands the median survival is 27 years. ${ }^{1}$

Research on the cost of care of patients with cystic fibrosis is scarce. ${ }^{2-5}$ Nowadays, however, there seems to be an increasing interest in this subject, possibly because of the recent discovery of the gene responsible for the disease which creates the possibility of population screening for carriers of the cystic fibrosis gene. The cost of care analysis presented here is part of a research project in which the costs, effects, and savings of screening for carriers of the cystic fibrosis gene in The Netherlands are estimated. ${ }^{6}$ We decided not to use data from the literature because we wanted to have agespecific cost estimates using primary data rather than using non-age-specific data and expert opinions.

The aim of the cost of care analysis is to estimate the following quantities using data collected from medical patient records and a patient questionnaire: (1) the age-specific medical consumption and medical costs of patients, and a breakdown of these costs into costs of hospital care, hospital and non-hospital medication, and home care with separate estimates for the (pre)terminal disease stage; (2) the lifetime medical costs of a patient by combining age-specific medical costs with recent survival figures of the Dutch cystic fibrosis registration ${ }^{1}$; and (3) the cost of care of cystic fibrosis in The Netherlands by combining age-specific medical consumption with the number and age distribution of patients in The Netherlands. ${ }^{1}$

The estimate of the lifetime costs of medical consumption of patients with cystic fibrosis will be used for cost-effectiveness calculations of nationwide screening programmes for cystic fibrosis carriers in The Netherlands.

\section{Methods}

The costs of medical consumption of patients with cystic fibrosis were divided into costs of hospital care (hospital days, consultations, diagnostic tests), hospital and home medication, and home care (visits to a general practitioner, physiotherapy at home, help from relatives, diet, travelling expenses, and special aids).

\section{MEDICAL CONSUMPTION}

To determine the cost of hospital care we reviewed the medical records of 81 patients (40 men) treated in a cystic fibrosis centre for adults in The Hague and in the Groningen University Cystic Fibrosis Centre for Children. We confined ourselves to hospital care during the years 1990 and 1991 to reflect recent clinical practice. An inventory was made of all admissions to hospital (hospital days, admissions, and consultations), visits to outpatient departments (consultations), radiological procedures, surgical interventions, laboratory investigations (tests), and other activities that were taken 
Table 1 Costs of several units of medical consumption by patients with cystic fibrosis based on estimates of real costs or on reimbursements

\begin{tabular}{lrl}
\hline Unit & Cost figure & Based on \\
\hline Hospital day & $£ 153.35$ & Estimate of real costs \\
Consultation & $£ 29.12$ & Estimate of real costs \\
Radiograph (average) & $£ 24.60$ & Reimbursement \\
Ultrasound (average) & $£ 51.93$ & Reimbursement \\
Doppler ultrasound & $£ 41.86$ & Reimbursement \\
CT scan & $£ 114.13$ & Reimbursement \\
Lung function test & $£ 65.62$ & Reimbursement \\
Laboratory (weighted average) & $£ 6.33$ & Reimbursement \\
\hline
\end{tabular}

in relation to cystic fibrosis. We also made an inventory of all medications taken in the hospital and at home. The cohort of patients analysed represents approximately $8 \%$ of all living patients in The Netherlands. The age distribution (median age 13; range 0-37 years) was similar to the age distribution of all patients in the Dutch cystic fibrosis registration which covers 3302 observed patient-years and has a $75 \%$ survival at 17 years and a $50 \%$ survival at 27 years. $^{1}$

To gain insight into the medical consumption that is not covered in the medical records we asked 73 patients to keep a diary of visits to the general practitioner and physiotherapist, and travelling expenses for one month. The response rate of this questionnaire was $64 \%$. We also questioned the patients about the support received from their social environment (for example, relatives), their daily activities, and their school/work life.

To check whether the medical consumption estimated from the medical records was in accordance with clinical experience, we interviewed several clinicians in charge of patients with cystic fibrosis. The results of the patient questionnaire were used to validate several data extracted from the patient records. The questionnaire itself was validated through interviews with some of the patients (or their parents) who completed the diaries.

The average age-specific medical consumption was obtained by dividing the age-specific consumption from the patient records and the patient questionnaires by the patient-years at risk in the age group concerned. Separate calculations were made for patients in the preterminal or terminal stage, defined as the last two years of life, because we expected that their medical consumption would differ significantly from the non-(pre)terminal patients.

costs

We estimated the costs from a societal point of view. Costs are measured by calculating invested manpower and materials with relevant wages and prices. These cost estimates will differ from those resulting from a financial point of view in which commercial prices are used including so-called transfer payments for example, profits, margins, tariffs, taxes, royalties. ${ }^{7}$ Whenever possible we used real costs per unit of medical consumption known from other research or estimated by us. If the real costs were not known, reimbursements from health care insurers were used (table 1 ). These reimbursements are the prices that insurers pay to hospitals, general practitioners, doctors, and other health care providers. The reimbursements are mostly settled in some form of negotiation between health care insurers and providers (for example, hospitals) and do not necessarily equate with real costs.

Most patients are treated in specialised cystic fibrosis centres or university hospitals. The costs of these hospital days are higher than for general hospitals because of the more intensive treatment. The costs of a hospital day include physiotherapy for 20 minutes a day. Children receive more physiotherapy (on average twice a day for 30 minutes) than adolescents who can perform their daily exercises mostly on their own; we therefore added the cost of 30 minutes physiotherapy to the costs of a hospital day for children.

The average age-specific medical costs are obtained by multiplying the average agespecific medical consumption by the corresponding unit cost figures. The age-specific figures were converted into the lifetime average consumption by using the Sum-Limit method ${ }^{8}$ which corrects for the year-to-year survival of patients with cystic fibrosis. To discount these costs we used a $5 \%$ discount rate towards the time of birth. Survival of patients with cystic fibrosis in The Netherlands was estimated from the Dutch cystic fibrosis registration. ${ }^{1}$

\section{Results}

The average consumption of the most important aspects of hospital care (except medication) is presented in table 2. "Consultations" include all visits of patients to the outpatients department. "Laboratory tests" represent the number of results of laboratory investigations (from blood, urine, and stool).

The estimates of the costs of home medication and home care were based on the patient questionnaire. Costs of home care include materials, diet, and travelling expenses. On average a patient visited the general practitioner

Table 2 Age-specific average hospital consumption of patients with cystic fibrosis per patient per year

\begin{tabular}{|c|c|c|c|c|c|c|c|c|}
\hline $\begin{array}{l}\text { Age } \\
\text { (years) }\end{array}$ & $\begin{array}{l}\text { No. of } \\
\text { patients }\end{array}$ & $\begin{array}{l}\text { No. of } \\
\text { hospital days }\end{array}$ & $\begin{array}{l}\text { No. of } \\
\text { admissions }\end{array}$ & $\begin{array}{l}\text { No. of } \\
\text { consultations }\end{array}$ & $\begin{array}{l}\text { No. of } \\
\text { radiographs }\end{array}$ & $\begin{array}{l}\text { No. of (Doppler) } \\
\text { ultrasound scans }\end{array}$ & $\begin{array}{l}\text { No. of lung } \\
\text { function tests }\end{array}$ & $\begin{array}{l}\text { No. of } \\
\text { laboratory tests }\end{array}$ \\
\hline $\begin{array}{l}0 \\
1-4 \\
5-9 \\
10-14 \\
15-19 \\
20-24 \\
25-29 \\
30-34 \\
35+ \\
\text { All }\end{array}$ & $\begin{array}{r}3 \\
11 \\
11 \\
21 \\
18 \\
9 \\
2 \\
5 \\
1 \\
81\end{array}$ & $\begin{array}{r}68.8 \\
7.2 \\
5.9 \\
4.9 \\
22.4 \\
52.6 \\
25.1 \\
6.5 \\
0.0 \\
18.5\end{array}$ & $\begin{array}{l}2.5 \\
0.4 \\
0.5 \\
0.4 \\
0.9 \\
1.6 \\
1.9 \\
0.7 \\
0.0 \\
0.9\end{array}$ & $\begin{array}{r}13.7 \\
6.4 \\
5.7 \\
5.3 \\
6.5 \\
7 \cdot 4 \\
8.9 \\
8.2 \\
4.0 \\
6.9\end{array}$ & $\begin{array}{l}6 \cdot 5 \\
2 \cdot 5 \\
2 \cdot 6 \\
2 \cdot 3 \\
4 \cdot 4 \\
8 \cdot 8 \\
4 \cdot 9 \\
3 \cdot 1 \\
1 \cdot 0 \\
4 \cdot 0\end{array}$ & $\begin{array}{l}0.5 \\
0.1 \\
0.3 \\
0.4 \\
1.0 \\
0.9 \\
0.5 \\
0.7 \\
0.0 \\
0.5\end{array}$ & $\begin{array}{r}0 \cdot 0 \\
0 \cdot 2 \\
5 \cdot 8 \\
7.9 \\
10 \cdot 4 \\
7 \cdot 3 \\
2 \cdot 4 \\
4.3 \\
2 \cdot 8 \\
5.3\end{array}$ & $\begin{array}{r}146.8 \\
57.5 \\
64 \cdot 8 \\
87 \cdot 1 \\
134 \cdot 2 \\
216.2 \\
128 \cdot 2 \\
141.8 \\
36.0 \\
116.5\end{array}$ \\
\hline
\end{tabular}


Table 3 Average cost of care (per patient per year) of patients with cystic fibrosis in 1991

\begin{tabular}{lcc}
\hline & Cost & Percentage \\
\hline Hospital care & $£ 4612$ & $42 \%$ \\
Medication & $£ 4067$ & $37 \%$ \\
Home care & $£ 2229$ & $20 \%$ \\
Total & $£ 10908$ & $100 \%$ \\
\hline
\end{tabular}

$2 \cdot 8$ times per year and the physiotherapist 31 times per year. Of all patients, $74 \%$ used a nebuliser, $54 \%$ a hometrainer for daily workouts, $11 \%$ an infusion pump, and $24 \%$ a positive expiratory pressure (PEP) mask. Only $11 \%$ did not use any device. For the devices we calculated the average yearly costs on an annuity basis. From the questionnaire we also learned that $57 \%$ of all adults had a paid job and about half of them $(47 \%)$ had part-time contracts.

The average cost of a patient with cystic fibrosis per year is $£ 10908$. Table 3 presents the breakdown of these costs. The total cost of care of cystic fibrosis in The Netherlands in 1991 is estimated to be $£ 10.9$ million, which is approximately $0.07 \%$ of the total health care budget in The Netherlands. This figure is obtained by multiplying the average costs per year with the number of patients (estimated at 1000 patients).

The cost of age-specific hospital care, medication, and home care is presented in the figure. The five year moving average is obtained by averaging the costs of the index year with the costs of the two preceding and the two following years. We have to keep in mind that from age 25 onwards our estimates are based on a relatively small group of patients (age $\geq 25$ years, $n=8$ )

A relatively high medical consumption occurs in the first year of life because the diagnostic process takes place in the first year of life in most $(57 \%)$ patients. ${ }^{1}$ The increase in average costs after the age of 15 is mainly due to frequent antibiotic treatment and hospital days (table 2) due to exacerbations or complications. Among the Dutch patients older than 31 years a relatively high proportion is diagnosed at an older age. Those patients have milder pulmonary disease, are less likely to suffer from pancreatic insufficiency or diabetes mellitus, and have consequently lower than average cost of care. ${ }^{9}$ The high values of the average costs at ages 25 and 30 shown in the figure are caused by two patients who underwent a lung transplantation (cost $£ 81895)$.

In order to arrive at the costs in The Netherlands we totalled the average cost per year of life up to the age of 35 which amounted to f614 587. When survival is taken into consideration, the lifetime costs of a patient with cystic fibrosis are $£ 409453$. If we discount the lifetime costs to the time of birth using a discount rate of $5 \%$, which is common in costeffectiveness studies, they amount to $£ 164365$.

The difference in costs between the average medical consumption of patients aged 15 and older who are not in the (pre)terminal phase and the average medical consumption of patients in the (pre)terminal stage amounts to f26599 which is $71 \%$ of the costs of the (pre)terminal stage (table 4). This difference is due to the large number of hospital days, radiographs, Doppler studies, and laboratory tests that are required. It is noteworthy that there is no big difference between the average cost of care of all patients $(£ 10908)$ and the cost of care for patients older than 15 years who are not in the (pre)terminal phase ( $£ 11$ 102). This can be explained by the relatively small number of patients in the (pre)terminal phase $(n=8)$ and the relatively low costs of patients under the age of 15 ( $£ 7759)$.

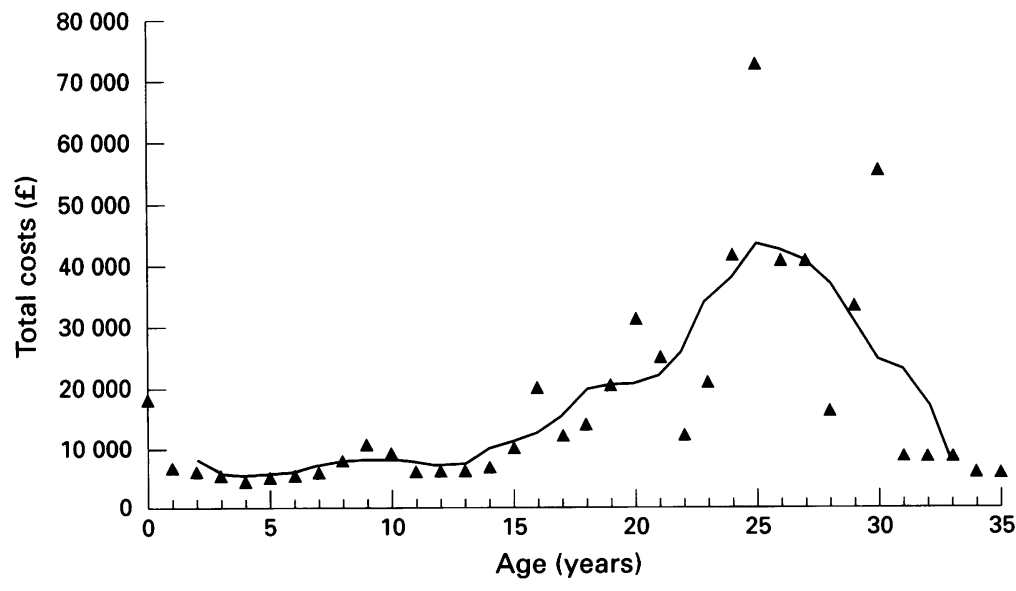

Average cost of care of patients with cystic fibrosis per year of age. $\mathbf{\Delta}=$ average cost per year; $-=$ moving average (five years).

\section{Discussion}

This study has focused on patients with cystic fibrosis in The Netherlands. In order to compare our findings with those of others, temporary price fluctuations in currencies have to be eliminated. All costs presented in this study are converted to pounds sterling by using the purchasing power parity (PPP) according to the Big Mac index for the corresponding countries, ${ }^{1011}$ adjusted to 1991 by using average annual inflation rates. ${ }^{12}$ The specific differences in health care organisation between countries are not considered in any PPP index (OECD or Big Mac). Van Ineveld calculated that the same set of health care services in the UK is $9 \%$ cheaper than in The Netherlands. ${ }^{13}$ We did not take this into account.

Table 4 Average medical consumption (per patient per year) of patients with cystic fibrosis aged 15 or older not in the (pre)terminal stage compared with the average consumption of patients in the (pre)terminal stage

\begin{tabular}{|c|c|c|c|c|c|c|c|c|}
\hline & $\begin{array}{l}\text { No. of } \\
\text { hospital days }\end{array}$ & $\begin{array}{l}\text { No. of } \\
\text { admissions }\end{array}$ & $\begin{array}{l}\text { No. of } \\
\text { consultations }\end{array}$ & $\begin{array}{l}\text { No. of } \\
\text { radiographs }\end{array}$ & $\begin{array}{l}\text { No. of (Doppler) } \\
\text { ultrasound scans }\end{array}$ & $\begin{array}{l}\text { No. of lung } \\
\text { function tests }\end{array}$ & $\begin{array}{l}\text { No. of } \\
\text { laboratory tests }\end{array}$ & $\begin{array}{l}\text { Average medical } \\
\text { consumption cost }\end{array}$ \\
\hline $\begin{array}{l}15+\text { years } \\
\text { (Pre)terminal }\end{array}$ & $\begin{array}{r}10 \cdot 9 \\
106 \cdot 0\end{array}$ & $\begin{array}{l}0 \cdot 8 \\
2 \cdot 7\end{array}$ & $\begin{array}{l}6 \cdot 5 \\
7 \cdot 9\end{array}$ & $\begin{array}{r}3.0 \\
15.9\end{array}$ & $\begin{array}{l}0 \cdot 3 \\
5 \cdot 4\end{array}$ & $\begin{array}{l}8 \cdot 7 \\
5 \cdot 5\end{array}$ & $\begin{array}{r}76 \cdot 3 \\
575 \cdot 5\end{array}$ & $\begin{array}{l}£ 11102 \\
£ 37701\end{array}$ \\
\hline
\end{tabular}


Our model of age-specific medical consumption seems plausible and the approach is also applicable to other countries. The lifetime costs of $£ 164365$ differ from other estimates. The OTA report estimates the lifetime costs of a patient with cystic fibrosis for 1989 at £72 166. ${ }^{3}$ This figure is obtained by discounting the average direct medical costs (average per year $£ 5618$ ) by $5 \%$ per year and correcting for survival in the USA. The difference between the OTA estimate and ours is probably due to primary data collection in our research (instead of using expert estimates). Ginsberg et al estimate the excess lifetime costs of patients to be $£ 129749,{ }^{4}$ which comes closest to our research. Although they made age-specific estimates of the costs, they did not always use data from real patients, and this may be the reason for the difference from our estimate.

All other known research on costs of cystic fibrosis differentiates between mild, moderate, and severe patients. ${ }^{2-5}$ Robson et al calculated costs to be between $£ 2792$ and $£ 19955$ per year with an average of $£ 8241$ for an adult patient. ${ }^{2}$ From our calculations the costs of an adult patient (aged 15 or over), excluding home care costs (for comparability), are $£ 14471$. In Denmark these costs were $£ 38963$ for three year old patients, $£ 36631$ for 12 year old patients, and $£ 65103$ for a 20 year old patient. ${ }^{5}$ Our calculations for these patients are, respectively, $£ 5590$ for patients of three years of age, $£ 6287$ for patients aged 12 , and $£ 31327$ for those aged 20 . These differences could again be the result of the use of expert estimates in the Danish study instead of using primary patient data.

Cystic fibrosis is a disease in which tremendous progress is being made in medical care. Some developments such as recombinant human DNase I to decrease the viscosity of purulent airway secretions, an increasing use of (heart-)lung transplantations, and home therapy have already become a reality since the time of this review, while others such as gene therapy have a possibility of progressing to the point of widespread clinical use. ${ }^{14-17}$ Although some of these developments can be very economical - for example, home therapy - most new developments are costly. ${ }^{18-22}$ Moreover, this progress in treatment will have an impact on the length and quality of a patient's life so that the costs of care for patients with cystic fibrosis will probably rise.

The indirect costs of patients have not been taken into consideration in this study. Indirect costs are mainly the result of production losses because patients (or their carers) are unable to work full time. Although American studies have tried to estimate these costs (for example, Pauly estimated the total cost for the cystic fibrosis population per year at $£ 44$ million $^{23}$ ), the use of such a method is disputed among economists. The so-called costs of "replacement" have also not been calculated and can only be calculated if a child born with cystic fibrosis was foregone and replaced by a child not affected with cystic fibrosis.

The daily costs of patients with cystic fibrosis such as diet appear to be relatively stable. The additional costs of, for example, frequent admission to hospital, and treatment with intravenous antibiotics fluctuate and depend on the age of the patient and stage of the disease. It is to be expected that daily costs will remain stable in the future, but additional costs will increase due to expensive new treatment and care provision. Because of better treatment and new medication, the lifetime cost of care will probably increase (higher medical consumption). This will lead to an ever increasing cost/savings balance of screening, as long as the growth in the costs of screening is lower than the growth in the lifetime costs of cystic fibrosis.

This study was made possible by a grant from the Praeventiefonds. We wish to thank all patients who cooperated by filling out the questionnaire.

1 Ten Kate LP, Halley DJJ. Genetische aspecten van 'cystic fibrosis'. Tijdschr Huisartsgeneesk 1995;12:195-8.

2 Robson M, Abbott J, Webb K, Dodd M, Walsworth-Bell J. A cost description of an adult cystic fibrosis unit and cost analyses of different categories of patients. Thorax 1992; 47:684-9.

3 US Congress Office of Technology Assessment. Cystic Fibrosis and DNA tests: implications of carrier screening. Washington, DC: US Government Printing Office, 1992.

4 Ginsberg G, Blau H, Kerem E, Springer C, Kerem B-S, Akstein $\mathrm{E}$, et al. Cost-benefit analysis of a national screenHealth Economics 1994;3:5-23.

5 Nippert I, Clausen H. Evaluating cystic fibrosis carrier screening development in Northern Europe: Denmark, the Federal Republic of Germany, the Netherlands, and the United Kingdom.

Dordrecht: Kluwer Academic Publishers Group (in press) bema JDF, Ten Kate LP. Costs of cystic fibrosis (CF) and
berijl JG, Hilderink HBM, Verheij JBGM, Kooij L, Habbema JDF, Ten Kate LP. Costs of cystic fibrosis (CF) and
costs of screening for CF carriers in the Netherlands. In: costs of screening for $\mathrm{CF}$ carriers in the Netherlands. In:
Escobar H, Baquero F, Suárez L, eds. Clinical ecology of Escobar H, Baquero F, Suárez L, eds. Clinical ecology of
cystic fibrosis. Madrid: Exerpta Medica, Elsevier Science Publishers, 1993:313-8.

7 Drummond MF, Stoddard GL, Torrance GW. Methods for the economic evaluation of health care programmes. Oxford: Oxford University Press, 1987.

8 Van Hout BA. Harttransplantaties. Kosten, effecten en prognoses (summary in English) [dissertation]. Erasmus University Rotterdam, 1990.

9 Gan KH, Heijerman HGM, Ten Kate LP, Scheffer H, Bakker W. Late diagnosis of cystic fibrosis: genetics and disease symptoms. Pediatr Pulmonol Suppl 1993;9:234.

10 The Economist year book. London: Economist Books, 1991.

11 The Economist year book. London: Economist Books, 1992.

12 The world in figures. London: The Economist Publications, 1994.

13 Van Ineveld BM, Van Oortmarssen GJ, De Koning HJ, Boer $\mathrm{R}$, Van der Maas PJ. How cost-effective is breast cancer screening in different EC countries? Eur f Cancer 1993; 29A: $1663-8$.

14 Tamm $M$, Higenbottam T. Heart-lung and lung transplantation for cystic fibrosis: world experience. Semin Respir Crit Care Med 1994;15:414-25.

15 Mylett J, Johnson K, Knowles M. Alternate therapies for cystic fibrosis. Semin Respir Crit Care Med 1994;15:426-33.

16 Wilson JM. Cystic fibrosis: strategies for gene therapy. Semin Respir Crit Care Med 1994;15:439-45.

17 Rosenstein BJ. Cystic fibrosis in the year 2000. Semin Respir Crit Care Med 1994;15:446-51.

18 Bosso JA, Stephenson STH, Herbst JJ. Feasibility and cost savings of intravenous administration of aminoglycosides in outpatients with cystic fibrosis. Drug Intell Clin Pharm 1985;9:52-4.

19 Donati MA, Guenette G, Auerbach H. Prospective controlled study of home and hospital therapy of cystic fibrosis pulmonary disease. $\mathcal{F}$ Pediatr $1987 ; 111: 28-33$.

20 Kane RE, Jennison K, Wood C, Black PG, Herbst JJ. Cost savings and economic considerations using home intravenous antibiotic therapy for cystic fibrosis patients. intravenous antibiotic therapy

21 Strandvik B, Hjelte L, Malmborg AS, Widen B. Home intravenous antibiotic treatment of patients with cystic intravenous antibiotic treatment of pati
fibrosis. Acta Paediatr 1992;81:340-4.

22 Bakker W, Vinks AATMM, Mouton JW, de Jonge P, Verzijl JG, Heijerman HGM. Continue intraveneuze thuisbehandeling van luchtweginfecties met ceftazidim via een draagbare pomp bij patiênten met cystische fibrose; een multicentrisch onderzoek. Ned Tijdschr Geneeskd 1993; 137:2486-91.

23 Pauly MV. The economics of cystic fibrosis. In: Lloyd-Still JD, ed. Textbook of cystic fibrosis. Boston: John Wright PSG Inc, 1983:465-76. 